\title{
Implementasi Kompetensi Profesional Guru Mata Pelajaran Tik Di Tingkat Smp Sekecamatan Paloh Kabupaten Sambas
}

\author{
Nurbani $^{\# 1}$, Maspian ${ }^{\# 2}$ \\ Program Studi Pendidikan TIK, IKIP PGRI Pontianak \\ Jl. Ampera No. 88 Pontianak \\ ${ }^{1}$ nurbani05egmail.com \\ 2lokomaspian@gmail.com
}

\begin{abstract}
Abstrack - This study has a general objective, namely to obtain information objectively about how to implement professional competence for ICT subject teachers at junior high school level in Paloh sub-district, Sambas district. This research is specifically to determine: (1) What is the Competence or Professional Ability of Teachers in ICT Subjects; (2) What is the teacher's ability to prepare learning; (3) How is the teacher's ability in implementing learning. The method in this research is survey research method. The population in this study were all teachers in Paloh sub-district, Sambas district, namely 27 teachers. In this study, data collection techniques are indirect communication techniques and documentary study techniques. The data collection tools in this study were questionnaires and observation sheets. The data analysis technique in the study used descriptive statistical data analysis. The results of the study concluded that: (1) The professional competence of teachers in this study was in the good category with an average of 72\%; (2) The teacher's ability to prepare the teaching and learning process in this study was in the good category, namely 79\%; (3) The teacher's ability in implementing and evaluating learning is in the very good category with an average of $86 \%$..
\end{abstract}

Keywords: Teacher Professional Competencies and ICT Subjects

Abstrak — Penelitian ini memiliki tujuan secara umum yaitu untuk mendapatkan informasi secara objektif mengenai Bagaimana Implementasi Kompetensi Propesional Guru mata pelajaran TIK ditingkat smp seKecamatan Paloh Kabupaten Sambas. Penelitian ini secara khusus untuk mengetahui: (1) Bagaimana Kompetensi atau Kemampuan Profesional Guru Pada Mata Pelajaran TIK; (2) Bagaimana kemampuan guru dalam menyiapkan pembelajaran; (3) Bagaimana kemampuan guru dalam pelaksanaan pembelajaran. Adapun metode dalam penelitian ini yaitu metode penelitian survey. Jumlah populasi pada penelitian ini yaitu seluruh guru sekecamatan Paloh kabupaten Sambas yaitu 27 orang guru. Dalam penelitian ini, teknik pengumpul data yaitu teknik komunikasi tidak langsung dan teknik studi dokumenter. Adapun alat pengumpul data pada penelitian ini adalah angket dan lembar observasi. Teknik analisis data dalam penelitian menggunakan analisis data statistik deskriptif. Hasil dari penelitian dapat disimpulkan bahwa: (1) Kompetensi profesional guru dalam penelitian ini dalam kategori baik dengan rata-rata sebesar 72\%; (2) Kemampuan guru dalam menyiapkan proses belajar mengajar dalam penelitian ini termasuk dalam kategori baik yaitu sebesar 79\%; (3) Kemampuan guru dalam pelaksanaan dan evaluasi pembelajaran termasuk dalam kategori sangat baik dengan rata-rata $86 \%$.

Kata Kunci: Kompetensi Profesional Guru dan Mata Pelajaran TIK

\section{PENDAHULUAN}

Di dalam perundang-undangan Nomor 14 tahun 2005 tentang guru dan dosen dituntut untuk memiliki kompetensi yang dapat mewujudkan pendidikan yang berkualitas [1]. Seorang guru atau dosen harus memiliki pengetahuan, perilaku yang baik dalam melaksanakan tugas dan kewajibannya.

Seorang guru atau dosen harus meningkan kemampuannya untuk mewujudkan kualitas pendidikan dan mutlak dilakukan. Dukungan pemerintah sangat diperlukan dan strategi pendidikan terus dilakukan untuk mencapai perubahan tersebut. Hal ini bisa dilakukan dengan perubahan kurikulum yang nantinya akan berefek pada kualitas pendidikan

Guru memiliki peranan penting di dalam peningkatan mutu. Untuk menghasilkan murid yang bermutu tidak terlepas dari guru yang berkompeten dalam mengajar. Untuk mencapai tujuan tersebut perlu ditingkatkan kemampuan guru yang benar-benar memiliki kompetensi.

Seorang guru dituntut memiliki tanggung jawab yang besar, ia harus menghadapi semua tantangan dan berani dilingkungan ia bekerja. Guru juga harus bisa menyesuaikan perkembangan zaman dan mengembangakan diri untuk 
menyempurnakan dirinya. Kesadaran seperti ini harus selalu dilakaukan demi menciptakan kualitas pembelajaran yang baik. Seorang guru harus memiliki empat kompetensi yaitu pedagogik, kepribadian, sosial dan profesional sesuai dengan Permendiknas Nomor 16 tahun 2007 [2].

Kompetensi pedagogik yaitu kemampuan mengelola siswa seperti pemahaman siswa, perancangan pembelajaran, evaluasi dan pengembangan siswa untuk merepresentasikan kemampuan yang mereka miliki. Kompetensi kepribadian yaitu kemampuan pribadi yang stabil, mantap, arif, dewasa serta berwibawa. Kemampuan sosial yaitu kemampuan guru untuk bersosialisasi dan berkomunikasi kepada siswa, sesama pendidik, tenaga kependidikan maupun orang tua siswa dan warga masyarakat sekitar. Kompetensi profesional yaitu kemampuan penguasaan materi yang diajarkan kepada siswa sehingga siswa dapat memahami materinya.

Muhammad surya menyatakan guru profesional adalah guru yang telah mendapat pengakuan secara formal berdasarkan ketantuan berlaku, baik dalam kaitan dengan jabatan ataupun latar belakang pendidikan formalnya [3]. Adapun kompetensi profesional sangat diperlukan bagi guru. Setiap jenjang pendidikan guru harus memiliki komptetensi professional. Selain itu guru harus bisa mengajar dan terampil dalam menerapkan media ajar, dan memiliki kepribadian yang baik dan bisa bersosialisasi dengan masyarakat. Kemampuan tersebut tidak bisa dipisahkan satu sama lainnya dan menyatu pada guru

Seorang guru harus dituntut professional sesuai dengan bidangnya. Misalnya guru dibidang TIK harus bisa mengoperasian komputer, menggunakan internet untuk sumber belajar, bisa memanfaatkan media komunikasi untuk kepentingan pembelajaran, serta bisa menjaga dan merawat peralatan komputer di laboratorium komputer. Berdasarkan hasil observasi di SMP se-kecamatan Paloh ditemukan sebagian guru tidak bisa memanfaatkan laboratorium komputer dikarenakan jumlah komputer yang masih terbatas. Kemudian jaringan internet di sebagian sekolah SMP masih kurang memadai sehingga guru menyampaikan materi dari sumber buku yang ada di sekolah untuk siswa belajar secara mandiri.

Mata pelajaran TIK masuk pada tahun 2004 dengan nama kurikulum berbasis kompetensi atau KBK 2004, kemudian diganti dengan Kurikulum Tingkat Satuan Pendidikan (KTSP) diman a setiap satuan pendidikan melakukan perencanaan, pelaksanaan, penilaian hasil pembelajaran, dan pengawasan proses pembelajaran untuk terlaksananya proses pembelajaran yang efektif dan efisien. Ada tiga aspek kajian untuk mata pelajaran TIK untuk jenjang SMP/MTs dan SMA/MA meliputi kompetensi ; (1) Konsep, pengetahuan, dan operasi dasar; kompetensinya adalah siswa mampu mengenali secara mendalam hakekat dan dampak TIK, etika dan moral pemanfaatan teknologi, media massa digital, masalah keamanan, dasar-dasar komputer, dan pengoperasian teknologi multimedia. (2) Pengolahan informasi untuk produktifitas; kompetensinya adalah siswa mampu menggunakan pengetahuan dan keterampilan untuk berbagai macam perangkat produktifitas teknologi meliputi: penggunaan sistem operasi; melakukan setting periferal; pengoperasian software; pemanfaatan jaringan. (3) Pemecahan masalah, eksplorasi dan komunikasi; kompetensinya adalah siswa mampu menerapkan lima pengetahuan dan keterampilannya dalam situasi kehidupan nyata untuk mendapatkan informasi, mengelola gagasan, memecahkan masalah, melakukan penelitian, dan menggunakan perangkat komunikasi untuk mendapatkan dan mengirimkan informasi.

Penilaian terhadap kompetensi profesional guru TIK tidak hanya itu saja, namun perlu diketahui dari indikator kompetensi profesionalnya yaitu penguasaan materi, kemampuan bertanya, mengadakan variasi kemampuan membuka pelajaran, kemampuan mengelola kelas, kemampuan pembelajaran, kejelasan dan penyajian materi, kemampuan menutup dan membuka pelajaran, dan ketepatan waktu dan pemberian materi pelajaran.

\section{Tinjauan Pustaka}

\section{A. Kompetensi Profesional Guru}

Dalam undang-undang nomor 14 tahun 2005 tentang guru dan dosen (pasal 1 ayat 4) dinyatakan bahwa profesional adalah "pekerjaan atau kegiatan yang dilakukan oleh oleh seseorang yang menjadi sumber penghasilan kehidupan yang memerlukan keahlian, atau kecakapan yang memenuhi standar mutu atau norma tertentu serta memerlukan pendidikan propesi [1]. Menurut Zuldafrial Kompetensi profesional merupakan kemampuan guru dalam menguasai pengetahuan bidang ilmu pengetahuan, teknologi, atau seni dan budaya yang di ampunya yang sekurang-kurangnya meliputi penguasaanm materi pelajaran secara luas dan mendalam sesuai dengan stsndar isi program satuan pendidikan, mata pelajaran atau kelompok mata pelajaran yang akan diampu. Selanjutnya menguasai konsep dan metode disiplin keilmuan, teknologi, atau seni yang relevan, yang secara konseptual menaungi dengan satuan pendidikan, mata pelajaran atau kelompok mata pelajaran yang diampu [4].

\section{B. Menyiapkan/Merencanakan Pembelajaran}

Tugas-tugas guru dalam perencanaan pembelajaran meliputi kemampuan dalam memahami tujuan pembelajaran, melakukan analisis pembelajaran, menerapkan sumbersumber pembelajaran, mengembangkan butir-butir tes, mengembangkan materi pelajaran, mengembangkan media dan metode pembelajaran, menerapkan sumber-sumber pembelajaran, mengoordinasikan segala faktor mendukung, mengembangkan dan melakukan penilaian awal terhadap rencana pembelajaran, merevisi pembelajaran, dan melakukan penilaian akhir terhadap rencana pembelajaran. Menurut Rusman, tahap perencanaan guru dalam kegiatan pembelajaran adalah tahap yang akan berhubungan dengan kemampuan guru menguasi bahan ajar. Kemampuan guru dalam hal ini dapat dilihat dari cara atau proses penyusunan program kegiatan pembelajaran yang dilakukan oleh guru [5]. 


\section{Melaksanakan Pembelajaran}

Menurut Zain "kegiatan belajar mengajar adalah suatu kondisi yang dengan sengaja diciptakan" [6]. Dalam pelaksanaan proses belajar mengajar menyangkut pengelolaan pembelajaran, dalam menyampaikan materi pelajaran harus dilakukan secara terencana dan sistematis, sehingga tujuan pengajaran dapat dikuasai oleh siswa secara efektif dan efisien. Kemampuan-kemampuan yang harus dimiliki guru dalam melaksanakan kegiatan belajar mengajar terlihat dalam mengidentifikasi karakteristik dan kemampuan awal siswa, kemudian mendiagnosis, menilai dan merespon setiap perubahan perilaku siswa.

Dengan demikian, dapat dikatakan bahwa melaksanakan proses belajar mengajar merupakan sesuatu kegiatan dimana berlangsung hubungan antara manusia, dengan tujuan membantu perkembangan dan menolong ketertiban siswa dalam pembelajaran. Pada dasarnya melaksanakan proses belajar mengajar adalah menciptakan lingkungan dan susana yang dapat menimbulkan perubahan struktur koginitis siswa.

\section{Matapelajaran TIK}

Menurut puskur Diknas (Pusat Pengembangan Kurikulum Pendidikan Nasional Indonesia): a. Teknologi Informasi dan Komunikasi (TIK) mencakup dua aspek, yaitu Teknologi Informasi dan Teknologi Komunikasi. Teknologi Informasi adalah meliputi hal yang berkaitan dengan proses, penggunaan sebagai alat bantu, manipulasi, pengelolaan informasi. b. Teknologi Kominikasi adalah segala hal yang berkaitan dengan penggunaan alat bantu untuk memperoses, manipulasi, pengelolaan, dan transper atau pemindahan informasi antar media.

Teknologi informasi dan komunikasi terdiri dari dua aspek, yaitu teknologi informasi dan teknologi informasi. Teknologi informasi, mempunyai pengertian luas yang meliputi segala hal yang berkaitann dengan proses, penggunaan sebagai alat bantu, manipulasi, dan pengelolan hal yang berkaitan dengan penggunaan alat bantu untuk memperoses dan menstranper data perangkat yang satu ke yang lainnya. karena itu, Teknologi informasi dan komunikasi adalah satu kesatuan yang tidak terpisahkan yang mengandung pengertiann luas tentang segala aspek yang terkaitan dengan pemrosesan, manipulasi, pengelolaan dan transper atau pemindahan informasi antar media menggunakan teknologi tertentu.

Pada hakekatnya, kurikulum Teknologi informasi dan komunikasi menyiapkan siswa agar dapat terlibat pada perubahan yang pesat dalam dunia kerja maupun kegiatan lainya yang mengalami penambahan dan perubahan dalam variasi informasi dan komunikasi untuk mencari, mengekspolasi, menganalisis, dan saling tukar informasi secara kreatif namun bertanggung jawab. Sebagai seorang pendidik khususnya guru bagaimana mengajarkan teknologi informasi dan komunikasi agar dengan cepat mendapatkan ide dan pengalaman dari berbagai kalangan masyarakat, komunitas, dan budaya, penambahan kemampuan karena penggunaan teknologi informasi dan komunikasi akan mengembangkan sikap inisiatif dan kemampuan belajar sendiri, sehingga dapat meningkatkan kompetensi propesional guru tik secara tepat dan optimal.

\section{METODE PENELITIAN}

Metode merupakan cara yang dilakukan peneliti untuk memecahkan permasalahan. Metode penelitian harus jelas dan sesuai dengan harapan sehingga peneliti dapat menyimpulkan dari rumusan masalah yang dibuat. Metode dalam penelitian ini yaitu metode survey.

Bentuk penelitian ini adalah penelitian deskriptif. Menurut Gall \& Borg, penelitian deskriptif dimaksudkan untuk membuat deskripsi yang cermat tentang suatu fenomena [7].

Populasi dalam penelitian ini yaitu semua guru di tingkat SMP sekecamatan Paloh Kabupaten Sambas yang menerapkan mata pelajaran Teknologi Informasi dan Komunikasi dengan jumlah guru 27 guru. Teknik pengumpul data yaitu teknik komunikasi tidak langsung dan teknik studi dokumenter. Sedangkan alat pengumpul data pada penelitian ini yaitu berupa angket dan lembar observasi. Teknik analisis data untuk menjawab permasalahan penelitian yaitu analisis data statistik deskriptif

\section{HASIL DAN PEMBAHASAN}

\section{E. Deskripsi Data}

1. Kompetensi Profefsional

Kompetensi profesional dari 27 guru yang diteliti masih tergolong baik, terbukti dari rata-rata $71,98 \%$. Untuk lebih jelas penilaian kompetensi profesional ke 27 guru dapat dilihat pada tabel 1 berikut.

Tabel I

Penilaian Kompetensi Profesional

\begin{tabular}{|c|c|c|c|c|c|}
\hline No & Kode & $\begin{array}{c}\text { Skor } \\
\text { Ideal }\end{array}$ & $\begin{array}{c}\text { Skor } \\
\text { Perolehan }\end{array}$ & Persentase & Kriteria \\
\hline 1 & G1 & 120 & 88 & $73 \%$ & Baik \\
\hline 2 & G2 & 120 & 80 & $67 \%$ & Baik \\
\hline 3 & G3 & 120 & 110 & $92 \%$ & $\begin{array}{c}\text { Sangat } \\
\text { Baik }\end{array}$ \\
\hline 4 & G4 & 120 & 57 & $48 \%$ & $\begin{array}{c}\text { Kurang } \\
\text { Baik }\end{array}$ \\
\hline 5 & G5 & 120 & 105 & $88 \%$ & $\begin{array}{c}\text { Sangat } \\
\text { Baik }\end{array}$ \\
\hline 6 & G6 & 120 & 74 & $62 \%$ & $\begin{array}{c}\text { Kurang } \\
\text { Baik }\end{array}$ \\
\hline 7 & G7 & 120 & 101 & $84 \%$ & $\begin{array}{c}\text { Sangat } \\
\text { Baik }\end{array}$ \\
\hline 8 & G8 & 120 & 71 & $59 \%$ & $\begin{array}{c}\text { Kurang } \\
\text { Baik }\end{array}$ \\
\hline 9 & G9 & 120 & 101 & $84 \%$ & $\begin{array}{c}\text { Sangat } \\
\text { Baik }\end{array}$ \\
\hline 10 & G10 & 120 & 94 & $78 \%$ & Baik \\
\hline 11 & G11 & 120 & 64 & $53 \%$ & $\begin{array}{c}\text { Kurang } \\
\text { Baik }\end{array}$ \\
\hline
\end{tabular}




\begin{tabular}{|c|c|c|c|c|c|}
\hline 12 & G12 & 120 & 57 & $48 \%$ & $\begin{array}{c}\text { Kurang } \\
\text { Baik }\end{array}$ \\
\hline 13 & G13 & 120 & 105 & $88 \%$ & $\begin{array}{c}\text { Sangat } \\
\text { Baik }\end{array}$ \\
\hline 14 & G14 & 120 & 74 & $62 \%$ & $\begin{array}{c}\text { Kurang } \\
\text { Baik }\end{array}$ \\
\hline 15 & G15 & 120 & 101 & $84 \%$ & $\begin{array}{c}\text { Sangat } \\
\text { Baik }\end{array}$ \\
\hline 16 & G16 & 120 & 57 & $48 \%$ & $\begin{array}{c}\text { Kurang } \\
\text { Baik }\end{array}$ \\
\hline 17 & G17 & 120 & 105 & $88 \%$ & $\begin{array}{c}\text { Sangat } \\
\text { Baik }\end{array}$ \\
\hline 18 & G18 & 120 & 74 & $62 \%$ & $\begin{array}{c}\text { Kurang } \\
\text { Baik }\end{array}$ \\
\hline 19 & G19 & 120 & 101 & $84 \%$ & $\begin{array}{c}\text { Sangat } \\
\text { Baik }\end{array}$ \\
\hline 20 & G20 & 120 & 71 & $59 \%$ & $\begin{array}{c}\text { Kurang } \\
\text { Baik }\end{array}$ \\
\hline 21 & G21 & 120 & 101 & $84 \%$ & $\begin{array}{c}\text { Sangat } \\
\text { Baik }\end{array}$ \\
\hline 22 & G22 & 120 & 94 & $78 \%$ & Baik \\
\hline 23 & G23 & 120 & 64 & $53 \%$ & $\begin{array}{c}\text { Kurang } \\
\text { Baik }\end{array}$ \\
\hline 24 & G24 & 120 & 110 & $92 \%$ & $\begin{array}{c}\text { Sangat } \\
\text { Baik }\end{array}$ \\
\hline 25 & G25 & 120 & 101 & $84 \%$ & $\begin{array}{c}\text { Sangat } \\
\text { Baik }\end{array}$ \\
\hline 26 & G26 & 120 & 71 & $59 \%$ & $\begin{array}{c}\text { Kurang } \\
\text { Baik }\end{array}$ \\
\hline 27 & G27 & 120 & 101 & $84 \%$ & $\begin{array}{c}\text { Sangat } \\
\text { Baik }\end{array}$ \\
\hline Rata-rata & & & $71,98 \%$ & Baik \\
\hline
\end{tabular}

\begin{tabular}{|c|c|c|c|c|}
\hline 7 & G7 & 14 & $93 \%$ & Sangat Baik \\
\hline 8 & G8 & 12 & $80 \%$ & Baik \\
\hline 9 & G9 & 12 & $80 \%$ & Baik \\
\hline 10 & G10 & 14 & $93 \%$ & Sangat Baik \\
\hline 11 & G11 & 11 & $73 \%$ & Baik \\
\hline 12 & G12 & 11 & $73 \%$ & Baik \\
\hline 13 & G13 & 12 & $80 \%$ & Baik \\
\hline 14 & G14 & 13 & $87 \%$ & Sangat Baik \\
\hline 15 & G15 & 10 & $67 \%$ & Baik \\
\hline 16 & G16 & 11 & $73 \%$ & Baik \\
\hline 17 & G17 & 14 & $93 \%$ & Sangat Baik \\
\hline 18 & G18 & 12 & $80 \%$ & Baik \\
\hline 19 & G19 & 12 & $80 \%$ & Baik \\
\hline 20 & G20 & 14 & $93 \%$ & Sangat Baik \\
\hline 21 & G21 & 11 & $73 \%$ & Baik \\
\hline 22 & G22 & 14 & $93 \%$ & Sangat Baik \\
\hline 23 & G23 & 12 & $80 \%$ & Baik \\
\hline 24 & G24 & 12 & $80 \%$ & Baik \\
\hline 25 & G25 & 14 & $93 \%$ & Sangat Baik \\
\hline 26 & G26 & 12 & $80 \%$ & Baik \\
\hline 27 & G27 & 12 & $80 \%$ & Baik \\
\hline \multicolumn{2}{|l|}{ Rata-rata } & & $80,49 \%$ & Sangat Baik \\
\hline
\end{tabular}

Terlihat dari tabel 2, terdapat 8 orang guru memiliki kesiapan dalam mengajar dengan tingkat kesiapan sangat baik dan 19 orang guru memilikai kesiapan dalam mengajar dengan tingkat kesiapan baik. Tingginya kesiapan guru dalam pembelajaran ditunjukkan dari semua guru yang menggunakan bahan pembelajaran disesuaikan dengan kurikulum yang berlaku. Materi yang akan diajarkan disesuaikan dengan perkembangan siswa, diurutkan dari yang termudah ke yang paling sulit. Media yang akan digunakan sesuai dengan tujuan pembelajaran, materi, metode pembelajaran, daya cerna siswa. Di samping media sebagai alat mempermudah pembelajaran, sumber belajar menjadi bagian yang penting. Perencanaan sumber belajar yang baik dapat menentukan kualitas pembelajaran yang akan dilaksanakan.

\section{F. Pembahasan}

Hasil dari penelitian ini menunjukkan kemampuan profesional guru mata pelajaran TIK di tingkat SMP SeKecamatan Paloh Kabupaten Sambas sebesar 71,89\% dengan kategori baik. Kompetensi profesional merupakan penguasaan materi yang dipersyaratkan bagi guru untuk meningkatkan pemahaman peserta didik sesuai dengan Standar Pendidikan Nasional (penjelasan PP No 19 Tahun 2005 Pasal 28 ayat 3 butir c) [8]. Sesuai dengan Permendiknas RI No 16 Tahun 2007 ada beberapa aspek yang dikuasai yaitu penginstalan program komputer, pengolahan lembar kerja, mengeksekusi ms word, membuat media presentasi interaktif sebagai media pembelajaran, menggunakakan media internet sebagai sumber materi untuk pembelajaran, mengoperasikan perangkat keras dan perangkat lunak sebagai pendukung pembelajaran. Data ini 
menunjukkan bahwa penguasaan materi guru TIK dalam kategori baik.

Menurut pendapat Uno, bahwa kompetensi profesional seorang guru adalah seperangkat kemampuan yang dimiliki guru agar ia melakukan tugas mengajarnya dengan berhasil [9]. Penguasaan materi merupakan point utama, karena sebagai dasar bagi guru untuk memberikan pembelajaran. Setelah materi dikuasai, guru juga harus mampu membuka pelajaran; mampu bertanya; mampu mengadakan variasi pembelajaran; mampu menjelasakan dan menyajikan materi, mengelola kelas, menutup pelajaran dan tepat waktu.

Untuk persiapan pembelajaran diperoleh skor sebesar $80,49 \%$ tergolong baik. Sebab semua kegiatan dalam persiapan pembelajaran disesuaikan dengan kurikulum yang berlaku. Guru harus mampu menyesuaikan materi pembelajaran dengan kondisi atau perkembangan siswa. Materi harus diurutkan dari yang sangat mudah sampai yang sangat sulit serta berdasarkan urutan yang logis. Media pembelajaran juga dipersiapkan sesuai dengan tujuan, isi materi, metode pembelajaran dan daya serap siswa. Selain itu sumber belajar disesuaikan dengan tujuan, materi, metode dan daya pemikiran siswa. Kegiatan proses pembelajaran direncanakan sesuai dengan materi, waktu, dan metode pembelajaran secara bervariatif. Semua itu terlihat dari rencana pelaksanaan pembelajaran yang disusun.

Hasil penelitian menunjukkan bahwa pelaksanaan dan evaluasi pembelajaran sebesar $83 \%$ dengan kategori sangat baik. Hal ini disebabkan karena para guru memiliki kompetensi pedagogik dan sosial secara baik. Langkahlangkah kegiatan pembelajaran dilakukan sesuai dengan prosedur yang benar. Guru memiliki kemampuan sangat baik dalam memberikan petunjuk dan penjelasan berkaitan dengan isi pelajaran, mampu mengekspresikan secara lisan dan tertulis yang mudah dimengerti oleh siswa, mendemonstrasikan materi secara cermat dan mutakhir, menginformasikan bahan pembelajaran sesuai dengan fakta yang ada, memelihara keterlibatan siswa karena mampu merespon secara positif atas partisipasi siswa dalam proses pembelajaran.

Hal tersebut didukung pula oleh penampilan guru di depan kelas yang sangat baik, menampilkan pembelajaran secara lancar dan menggunakan bahasa secara komunikatif dalam proses pembelajaran. Pelaksanaan pembelajaran yang baik tersebut karena pengalaman mengajar sebelumnya yang sudah tidak diragukan lagi, meskipun mereka harus mengajar materi TIK yang bukan bidangnya. Hanya berbekal pengetahuan tentang komputer, cara mengoperasikan MS word, power point dan excel, para guru mampu menampilkan pembelajaran secara baik. Hal ini disebabkan karena pada tingkat SMP materi TIK masih bersifat pengenalan perangkat lunak dan keras.

\section{KESIMPULAN}

Berdasarkan dari hasil analisis data dan pembahasan penelitian yang telah diuraikan pada BAB IV, maka dapat diambil kesimpulan sebagai berikut: (1) kompetensi profesional guru mata pelajaran Teknologi Informasi dan Komunikasi (TIK) di tingkat SMP SeKecamatan Paloh Kabupaten Sambas dalam penelitian ini termasuk baik terbukti dari rata-rata sebesar 71,89\%; (2) kemampuan guru dalam menyiapkan proses belajar mengajar pada mata pelajaran TIK tingkat SMP SeKecamatan Paloh Kabupaten Sambas dalam penelitian ini termasuk baik yaitu sebesar $80,49 \%$. Tingginya kesiapan guru tersebut karena adanya tuntutan dari sekolah dan kebiasan-kebiasan guru sebelumnya yang selalu menyiapkan proses pembelajaran secara baik; (3) kemampuan guru pada pelaksanaan dan evaluasi pembelajaran pada mata pelajaran TIK tingkat SMP SeKecamatan Paloh Kabupaten Sambas dalam penelitian ini termasuk sangat baik dengan rata-rata 83\%. Dalam kegiatan ini kemampuan yang dituntut adalah keaktifan guru menciptakan kreatifitas dan menumbuhkan kegiatan siswa belajar sesuai dengan rencana yang telah disusun serta menyertakan siswa. Guru harus dapat mengambil keputusan atas dasar penilaian yang tepat, apakah kegiatan belajar mengajar disesuaikan dengan kemampuan siswa, apakah metodenya diubah, apakah kegiatan yang lalu perlu diulang, manakala siswa belum dapat mencapai tujuan pembelajaran [5]. Pada tahap ini disamping pengetahuan teori belajar mengajar, pengetahuan tentang siswa, diperlukan pula kemahiran dan keterampilan teknik belajar, misalnya: prinsip-prinsip mengajar, penggunaan alat bantu pengajaran, penggunaan metode mengajar, media pengajaran dan keterampilan menilai hasil evaluasi siswa.

\section{UCAPAN TERIMA KASIH}

Peneliti mengucapkan terimakasih kepada sekolah SMP Negeri se Kecamatan Paloh yang sudah memberikan izin kepada peneliti untuk melaksanakan penelitian. Kemudian, tidak lupa penelti ucapakan kepada IKIP PGRI Pontianak yang sudah memberikan sumbangsih pembiayaan kepada peneliti dalam pelaksanaan penelitian

\section{DAFTAR PUSTAKA}

[1] D. P. Nasional, "Undang-Undang Nomor 14 Tahun 2005 Tentang Guru dan Dosen,", dalam Depdiknas, Jakarta, 2005.

[2] R. Indonesia, Permendiknas No.16 Tahun 2007 tentang Standar Kualifikasi Akademik dan Kompetensi Guru, Jakarta: Sekretariat Negara, 2007.

[3] M. Surya, Psikologi Guru konsep dan Aplikasi Dari Guru Untuk Guru, Bandung: Alfabeta, 2014.

[4] Zuldafrial, Kompetensi Profesional Guru Mata Pelajaran, Pontianak: IAIN Pontianak Press, 2017.

[5] Rusman, Manajemen Kurikulum: Seri Manajemen Sekolah Bermutu, Jakarta: PT.Raja Grafindo Indonesia, 2018.

[6] D. d. Z. Aswan, Strategi Belajar Mengajar, Jakarta: Rineka Cipta., 2016.

[7] B. \&. Gall, Education Research, New York: Allyn and Bacon., 2003. 
p-ISSN : 2640-7363

e-ISSN : 2614-6606

[8] P. P. R. Indonesia, Peraturan Pemerintah Republik Indonesia Nomor 19 tahun 2005 tentang Standar Nasional pendidikan, Jakarta: Departemen Pendidikan Nasional, 2005.

[9] H. B. Uno, Teori Motivasi dan Pengukurannya, Jakarta: Bumi Aksara, 2008 